\title{
Analysis on the Path of Campus Culture Construction in Private Colleges and Universities in the New Period
}

\author{
Zhenpeng Zhao \\ College of Art and Design \\ Huanghe Science and Technology College \\ Zhengzhou, China 450006
}

\begin{abstract}
At present, there exist various problems in the construction of campus culture in private universities, including the lack of culture spirit in campus environment, unsound campus culture system, outstanding phenomenon of the rule of men, and the short of campus spirit and culture. Therefore, private colleges and universities should adopt measures to carry out cultural construction in campus by improving the campus environment, amplifying rules and regulations, and accumulating spirit of campus.
\end{abstract}

Keywords-private colleges and universities; campus culture; construction

\section{INTRODUCTION}

Campus culture has abundant connotations with narrow and broad. The campus culture in broad sense includes material culture (including the school's architectural style, campus sculpture, campus scenery spots, billboards, etc.), system culture (including the campus rules and regulations, the campus common behavior etc.) and spiritual culture (including campus shared values as well as campus activities and public opinions which show the common value).

All aspects of campus culture play a very important role in the healthy development of universities. Beautiful, harmonious and orderly campus environment brings people harmonious beauty and positive power. Under the influence of the environment, teachers and students working and learning in the environment can cultivate tastes, exercise qualities and shape their spirits in an imperceptibly way to achieve the internalization of external and harmonious factors that precipitate in the environment. Thereby, it can be sublimated to individual harmonious consciousness and harmony state. The scientific and sound system culture can provide a broad stage for teachers' professional development, and create a platform for administrators' talents as well as provide the best education, teaching and administrative services for students' growth, and then provides the basis for the comprehensive promotion of teachers and students in their work, study, life and other aspects. The campus spirit culture is the intensive reflection of the school's personality and spirit, and it also plays an important role in the harmonious consciousness and spirit of the teachers and students. The campus spirit culture of universities reflects the values of the school mainly through its guidelines, university spirits, teaching and learning styles and so on. While campus cultural activities pull teachers and students into a group from independent individuals, in which teachers and students can get education and inspiration.

\section{The CURRENT SituAtion OF CAMPUS CUlture IN PRIVATE COLLEGES AND UNIVERSITIES}

After over twenty years of development, although the campus culture of private colleges and universities has certain developments generally, there are still some problems that need to be solved urgently:

\section{A. Campus Environment}

The vast majority of private vocational colleges have reached a certain level in the construction of material culture. Through breaking through the bottleneck of fund, some private vocational colleges with strong force are comparable with even exceed the state universities in the aspects of campus geographical environments, floor areas, architectural artistic levels and styles, activity venues, teaching facilities, library construction and others. The construction of the campus environment of these private colleges is advanced, and it has a positive and aesthetic impact on staff and students, and it also lays a solid foundation for the construction of the integrated system of campus culture. However, there are some private universities having not got rid of the financial pressure in the construction of campus culture environment, and it lacks longterm planning in the overall construction of the campus, shows up as an unreasonable layout of school buildings without sufficient landscape facilities, being ineffective in infecting, educating or edifying people through its beautiful environment.

\section{B. Rules and Regulations}

Private colleges and universities have relatively complete management system, organizational structure, and certain organization and management abilities. However, there still exist many problems in the construction of management teams, management capacities and levels and other soft elements. It's easy to cause a stop-gap situation in management. More serious problems are showed in the randomness of 
organizational decision and management, which result in poor belonging of teachers and students as well as organizational cohesion on account of working regardless of systems, though it seems like a sound system.

\section{Spiritual Culture}

Private Colleges and universities have not yet formed core values in the spiritual and cultural level. Due to lack of thinking on macro-strategic problems including the guiding ideology and the idea of running a school, private colleges and universities did not fully realize the importance and value of campus culture in the development of the school. Therefore, strictly speaking, at present, there have not yet appeared private colleges and universities in China, which have unique cultural and spiritual characteristics, impressive mark in the behaviors and speeches of teachers and students as well as unified cultural symbols. Although private colleges and universities always carry out a variety of campus cultural activities actively and student organizations also have management system, there are also some problems, such as campus cultural activities without guiding ideology or longterm planning, simple, disorder and formalized activity designs without depth, prominent characteristics of entertainment and secularity in campus cultural activities, lots of activities without specialty characteristics; serious lack of academic atmosphere, low participation rate of students in campus cultural activities.

\section{THE REASONS FOR CAMPUS CULTURAL CONSTRUCTION LAGGING BEHIND IN PRIVATE UNIVERSITIES}

\section{A. Institution Limitations}

There are more or less problems in the system of many private colleges and universities. Many private colleges and universities adopt the management mode of "parent system" or "family style". The phenomenon of "rule of man" is more prominent under the management mode, the development of school is largely determined by the principal himself or his family. It's known that joint efforts of teachers and students are needed in the construction of campus cultures, however, the system of private colleges and universities makes it difficult for teachers and students to integrate into the development of school.

\section{B. Teachers Limitation}

Campus culture construction needs the support of a strong teaching staff. On the whole, private college teachers team is not reasonable including unreasonable age structure (the elderly and young teachers more while middle aged teachers less), unreasonable educational levels (teachers with higher diploma are less, while teachers with lower diploma more), and unreasonable levels of teachers' professional titles (teachers with senior professional titles are less, while teachers with junior-titles more), in the meanwhile, the stability of teachers in private colleges can not be guaranteed. The teachers team above lead to some teachers playing the role of marginal men and spectators in the campus culture construction, that's why the construction of campus culture lacks the guiding and core force.

\section{Poor Source of Students}

In the present stage of higher education enrollment, private universities in the same level are always in the last row, meaning bad universities, and its enrollment of students' qualities are lower than that of public institutions. "A number of indicators such as the students' learning enthusiasm, social motility, expectations and other index are lower [1]. Limited by students' quality, it is difficult for private colleges and universities to carry out cultural activities on campus in width and depth, which increases the difficulty for the private colleges to carry out campus culture construction.

\section{Lack of Funds}

With government financial allocations, tuition fees become the sole source of funds for many private colleges and universities. Without the support of adequate funds, the construction of campus culture cannot obtain good results. However, for some private universities with a short history, they regard the tuition fees as the only income in small scale, such spending can often be saved whenever possible.

\section{The PATH OF CAMPus Culture CONSTRUCTION IN PRIVATE COLLEGES AND UNIVERSITIES}

Private colleges should not neglect the important problem that campus culture plays an important role in the process of the healthy development of colleges and universities. They should focus on the weakness in the campus culture, and take effective measures to build campus culture. The measures should include six ways:

\section{A. To Set up Special Funds}

Campus culture construction has penetrated into all aspects of school life, and it cannot be built well just by one or several departments. The idea that the construction of campus culture just is the responsibility of the department of student management, ideological education and propaganda is narrow and harmful. In order to do the construction of campus culture well, colleges should, first of all, promote the thoughts of college leaders, and it's better to set up the position of vice president to take charge of related issues about campus culture construction. Secondly, special funds for the construction of campus culture should be established, and being carried out every year according to a certain budget, and special fund should be available. There exist some schools whose construction fund is even less than the budget. Thirdly, the construction of campus cultural talents should be improved, through the guidance of propaganda department, participation of teachers and students, and years of accumulation can the construction effect of campus culture be achieved.

\section{B. To Beautify Campus Environment}

Private colleges and universities should strengthen the construction of campus environment to actively create a "healthy and positive, clean and beautiful, harmonious and unified" campus. The layout of the campus environment should be designed carefully and made economical and practical, also the overall planning should be focused on and adjusted according to local conditions, and circumstance. 
Besides, ideological and cultural education should be contained in the environment construction to achieve the combination of art and times. Through the decoration on campus architectures, working office, and classrooms; planting and cultivation of flowers and trees; display of campus sculptures; the suspension of celebrity portraits, famous aphorism, and works of art; it gives a tree-lined and beautiful environment to campus, in which teachers and students can cultivate their tastes, purify minds and sublimate thoughts while enjoying the beautiful scenery. What's more, in order to make the environment specialized, modernized and matched with education well, teaching staff and students teach and learn happily as well as being enlightened and educated under the subtle influence, private universities should invest more on teaching facilities, enriching and updating professional teaching equipment constantly, and expanding the campus network.

\section{To Improve Rules and Regulations}

The formulation of the rules and regulations of private colleges and universities should focus on three aspects. Firstly, it should reflect its own characteristics. Chinese private universities should change the wrong ideas in the past from copying public school rules and regulations to formulate their own rules based on their objective reality to manifest their significant characteristics. Secondly, it should embody democracy principles. Due to the bottleneck of school system (family management mode), the formulation of rules and regulations of some private universities in the past lacks democracy, and it also caused a lot of drawbacks. Therefore, private colleges and universities should listen to teachers and students' views widely in the future formulation of rules and regulations and make them reflect reasonable views of teachers and students. Thirdly, it should implement effectively. Private colleges and universities should strengthen the openness and transparency of systems, strengthen supervision, enforce laws strictly, and work according to laws to maintain the authority and dignity of system, achieve the highest culture system, maximize the function of system, and provide strong guarantee for building a harmonious campus for private universities.

\section{To Concise University Spirit}

The cohesion of campus culture is the spirit of the school, also known as the soul of the school, its formation undergoes a long-term historical accumulation. As the inner core of campus culture, it has a strong cohesion and solidarity. Once a good school spirit is formed, it will become a great impetus to the school's development. In the construction of spiritual culture in private universities, a clear "university spirit" should be firstly established". "The reason that a great organization can survive for a long time, the most important condition is not the structural form or the management skill, but the spiritual strength that we call faith and the appeal of this belief to all the members of the organization". [2] The second aspect of the spirit culture construction in private universities is that the construction of school spirit takes strengthening teaching, learning, leading cadres and party styles as the main content. Private colleges and universities should strengthen the construction of party and leading cadres styles to create a good atmosphere of honest and diligent government, unity and cooperation to achieve management education. Besides, teachers' ethics should be paid special attention, in the meanwhile, private universities should build a good teaching atmosphere and create a good learning style actively.

\section{E. To Strengthen the Teaching Staff}

Private colleges and universities should establish a teaching group of high quality, which is the key to improve humanistic quality of college students. Private universities should firstly introduce talents, adjust the age structure of teachers in two big and middle small, and increase the proportion of young and middle-aged teachers. Secondly, adopting the correct proportion of full-time and part-time teachers according to the actual situation, and stabilizing the core teachers are the precondition of the existence and development of the school. Besides, it is an objective standard for the quality of education to raise the overall diploma level of teachers. What's more, scientific guidance of people-oriented should run through the construction of teachers, and teachers' qualities of all aspects should be improved.

\section{F. To Regulate Campus Activities}

Private colleges and universities should pay attention to the guidance and management of campus activities. In order to regulate campus activities, private colleges and universities should, first of all, increase the academic breadth of campus activities. In addition to this, private colleges and universities should organize academic lectures regularly, and invite experts in certain fields inside and outside the school to make a special report for teachers and students to broaden teachers and students' views. Secondly, private colleges and universities should strengthen the positive guidance of the various associations in the school and provide special teachers for their guidance to guide these associations develop toward the positive and rich, healthy and colorful direction. Finally, private universities should also organize some regular campus recreational activities, such as welcome party, New Year party, campus singer contest, speech contest to provide recreational opportunities for teachers and students and enrich campus life.

\section{CONCLUSION}

From the perspective of history, the university campus culture is gradually formed along with the development of higher education. The development of higher education is the development process of university campus culture. Generally speaking, as a unique cultural phenomenon of colleges and universities, university campus culture is created and gradually formed in the long-term school running. The culture, on the one hand, has been widely recognized and followed by the teachers and students of the school; on the other hand, it also has become ideas and spiritual symbols of the school characteristics. The construction of campus culture should propagandize campus culture by making full use of various channels and internalize external requirements into self-pursuit of campus people. College campus culture is the common value standard, basic information and behavior standard of teachers and students. Meanwhile, it's also a kind of cultural pattern. Due to existing for just a short time, lacking rich historical accumulation, Chinese private colleges and 
universities have some deficiencies in the construction of campus culture. For private colleges, strengthening the construction of campus culture and forming unique cultural connotation and culture brand are more needed, only by doing those can they get continuous accumulation and development of the school, improve the popularity and reputation, and promote the development of private universities.

In conclusion, the campus culture plays a very important role in the healthy development of colleges and universities, which should be paid attention by university workers. However, there still exist many problems in the construction of campus culture, only by facing up to these problems and find out the solutions can private colleges and universities make great progress in the construction of campus culture.

\section{REFERENCES}

[1] Chen Hui. Cases Study and Revelation of the Construction of Campus Culture in Chinese and Universities [J]. Chinese Geological Education, 2006, 01:137-141.

[2] Liu Longhai. Strengthening the Construction of University Campus Culture and Realizing the Management of People Oriented [J]. China Higher Education Research, 2007, 01:84-85.

[3] Yang Shuzi. Campus Culture and the Spirit of the Times [J]. China Higher Education Research, 2007, No.16303:3-7.

[4] Zhu Yifeng. Analysis of the Construction of the University Campus Culture Brand [J]. Journal of Zhejiang Normal University (Social Science Edition), 2007, No.15003:119-121.

[5] Zhou Fengrong. Analysis on the Construction of Campus Culture in Chinese Private Colleges and Universities [J]. Journal of Hunan University of Science and Engineering, 2006 (2): 210-212.

[6] Liu Huifang, Ye Yunfeng, Cheng Min. Study on Reasons of Campus Culture loss in Private Colleges and Constructing Approaches [J]. The Guide of Science and Education, 2015, 12:17-18. (late)

[7] Chen Yuzhong, Li Zhenghua, Zhong Lichuan. Study on the Construction of the University Campus Culture [J]. Theory and Reform, 2007, No.15806:101-103. 